Article

\title{
Infrastructure Development and Waterfront Transformations: Physical and Intangible Borders in Haifa Port City
}

\author{
Keren Ben Hilell * and Yael Allweil \\ Architecture and Town Planning Faculty, Technion IIT, Israel; E-Mails: keren-ben@campus.technion.ac.il (K.B.H.), \\ aryael@technion.ac.il (Y.A.) \\ * Corresponding author
}

Submitted: 17 February 2021 | Accepted: 16 April 2021 | Published: 27 July 2021

\begin{abstract}
Constructed on its natural bay as a fortified Muslim town in the late 18th century, Haifa's port city transformed into a modern cosmopolitan port city in the second half of the 19th century. Significant technological, administrative, and social changes made Haifa into the transportation and economic hub of northern Palestine: Its harbor, the first in the region, became a gate to the east for commodities, pilgrimages, and ideas. British imperialism enlarged it with landfill areas and added an industrial function, constructing refineries and a connecting pipeline with Iraq. Haifa port served as the main entry port for immigration and goods for the newly founded Israeli state. Privatization and neo-liberalization transformed it from national port to international corporate hub, reshaping both port and city. Individual entrepreneurs, local governments, and imperial actions shaped and reshaped the landscape; perforating new access points, creating porous borders, and a new socioeconomic sphere. This process persisted through the Late Ottoman era, the British Mandate, and the Israeli state. From the first Ottoman landfills to the sizeable British harbor of 1933, the market economy led urban planning of Haifa's waterfront and its adjacent railroad to the current Chinese petrol-harbor project. What were the city's tangible and intangible borders? How did these changes, influenced by local and foreign agendas, unfold? Tapping into built-environment evidence; archival documents (architectural drawings, plans, maps, and photographs); and multidisciplinary academic literature to examine Haifa's urban landscape transformation, this article studies the history of Haifa's planned urban landscape-focusing on transformations to the port and waterfront to adjust to new technologies, capital markets, and political needs. We thus explore Haifa port history as a history of porosity and intangibility-rather than the accepted history of European modernization-building upon theoretical literature on global networks and urban form, regional dynamics of port cities, and tangible and intangible border landscapes.
\end{abstract}

\section{Keywords}

Haifa; infrastructure development; Israel; modernity; porosity; port city

\section{Issue}

This article is part of the issue "Planning for Porosity: Exploring Port City Development through the Lens of Boundaries and Flows" edited by Carola Hein (Delft University of Technology, The Netherlands).

(C) 2021 by the authors; licensee Cogitatio (Lisbon, Portugal). This article is licensed under a Creative Commons Attribution 4.0 International License (CC BY).

\section{Introduction}

Ports and port cities present a history of spatial situations defined by flexible borders, as porous access points connecting distant places and facilitating movement of goods and people worldwide. Natural harbors, developed into ports, gave rise to numerous cities on rivers and seas, fundamental infrastructure for economic development and cultural interconnection. Ports provided the necessary facilities to connect land and water transport, including the development of docks and breakwaters, redesigned coastlines, and landed infrastructure at the intersection of water and land. These spatial elements enable the porosity of tangible borders. Therefore, the 
elaborate infrastructure of piers, wharves, docks, and warehouses-produced for transhipment of goods and people-constitutes a porous border demarcating tangible borders as intangible borders. Around the world, these intangible borders attracted markets and trade, significant brokerage and exchange, and the formation of permanent settlements: the port cities (Hein, 2014).

Port infrastructure and landed structures were crucial for port survival, an issue of imperial and national importance involving commercial and cultural interest groups. As the nature of goods changes, ships' nature and docking infrastructure change accordingly. This has accelerated with industrialization in the 19th and 20th centuries (Miller, 2012). More extensive and more specialized ships-sail ships to steamships, to container ships and oil tankers-demanded deeper docking pools and larger cranes, railways, warehouses, administrative areas, and worker housing. They changed the waterfront and urban fabric of port cities, and the grain of porosity required of port landscapes. Transformations to London, New York, and Rotterdam's well-researched ports portray the tremendous impact of port infrastructure development on the port city and its bordering geography (Meyer, 2003; Smith \& Ferrari, 2012).

Because of geographical, political, economic, historical, climatic, and other attributes, port cities differ in their specific landscapes of intangible borders. This article studies Haifa's port and port city's history as a sphere of intangible global and local borders since the mid-18th century. It depicts a specific history of porosity transcending Haifa's accepted, bracketed history in the context of Empire, colonialism, nationalism, and globalization. Our findings indicate that Haifa's water and landed infrastructure constantly transformed the water and landed borders of its port responding to changes in transported goods (cotton, crude oil, immigrants, etc.), movement direction (in or out), and the technological challenges these changes posed to the port's survival. Further, our findings indicate that a diversity of actors were involved in constructing Haifa's port infrastructure and the city, with significant implications for the nature and location of border spheres. Haifa started as a local-dominated port, exporting cotton to Europe as an alternative to Acre's Ottoman-dominated port. In the second half of the 19th century, the Ottomans transformed it into a modern cosmopolitan port city. The British Mandate of Palestine designated it as the Empire's main port in the Eastern Mediterranean for crude oil from Iraq. Haifa port served as the main gateway for Israel since statehood. Run by global corporations, Haifa port has transformed again into a global container port. To explore this history as a history of porosity and intangibility-rather than the accepted history of European modernization - this article builds upon three spheres of theoretical literature: global networks and urban form; regional dynamics of port cities; and tangible and intangible border landscapes.

\section{Theoretical Framework}

\subsection{Global Networks and Urban Form}

Port cities are unique in the built environment for providing a water-land transition space (Hein, 2011, 2016; Hoyle, 1989; Hoyle et al., 1988). Ports constitute the spatial infrastructure for the transmission and exchange of people, materials, and ideas in a network system that connects the nodes of the global geography of commerce (Castells, 2000). The design and development of port facilities and land connections to the port determined port survival over time and constituted an issue of social, political, and economic importance: "In the process, they added layer upon layer to social and cultural networks and inscribed wealth into the built environment, building and rebuilding port infrastructure and urban structures" (Hein, 2014, p. 342). Understanding the landscape of ports and port cities as instruments for forming and sustaining the port as a global node is vital for studying this phenomenon.

Port landscapes were reshaped by new infrastructure technologies as maritime steam engines increased marine trade in quantity and speed (Carmel, 2010; Kitsikopoulos, 2013; Kozlovsky \& Grobman, 2017). Railroads and steam-powered trains spread goods and peoples inland (Amit, 2007; Christensen, 2017; Hein, 2014; Simonowitz, 2014). The oil industry facilitated the new Petroleumscape of refineries and gas stations (Barrett \& Worden, 2014; Hein, 2018; Szeman, 2012; Watts, 2009), while containerization separated cities from ports, creating industrial zones (Hein, 2016; Hoyle, 1989; McGovern, 2008). Adaptation of the ports, urban structures, and their natural environment following new technologies, shipping needs, and ideas required planning and collaboration between public and private actors (Hein, 2014).

In the last thirty years, planning theory and practice has changed from traditionally precise bounded scales (national, regional, local) to the study of transgeographical landscapes, focusing on networks, hubs, webs, corridors, flows, zones, and soft spaces (Castells, 2000; Graham \& Healey, 1999; Heley, 2013; Paasi \& Zimmerbauer, 2016). While much of contemporary scholarship on globalization focuses on fast modes of transportation (planes, trains, and cars) arguably globalization is more effectively enacted through ports. There, regional and global networks connect, transforming and developing the built environment and urban form. The global shipping market transports most commodities globally $(90 \%)$, in line with their historical role as global nodes (Hein, 2016). The disciplines involved in the study of port cities include history, economics, transportation, and ecology, requiring further inquiry into the history of architecture and urban planning, focusing on the longue durée of transforming port landscapes (Hein, 2016). 


\subsection{Geographic Dynamics of Port Cities: Politics, People,} and Built Environment

Port cities attract people, power, social and cultural capital. Empires, states, and regional authorities struggle to control and annex them to their territory and operate through them (Driessen, 2005; Hein, 2010, 2014). Commercial companies and individual entrepreneurs participate in political struggles representing their countries and communities, often waged via the port's development and infrastructure (Dündar et al., 2014; Hein, 2016). Space is a social product resulting from constant ongoing struggle between diverse political agendas, ideologies, narratives, and motivations (Lefebvre, 1991). Port cities represent a rich history of such social productions of space, where struggles over territorial control changed the borders of regions, states, and empires in the course of history.

In the Eastern Mediterranean, borders have changed dramatically in the 19th and 20th centuries as Empires, European powers, and the Ottomans have raced for economic and religious power, shifting regional borders through governmental reforms and war (Kark \& Frantzman, 2010; King, 2015). With the rise of nationalism in the MENA and particularly the Israeli-Palestinian conflict over Palestine's territory, borders were rapidly drawn and redrawn, determining spheres of affiliation, identity, and recognition (Allweil, 2016, 2017; AlSayyad, 1995; Said, 1979). In the age of capitalism and global markets, spatial conflicts shifted again from nationalreligious to civil society, with diverse social groups struggling for the right to space (Jabareen, 2015; Yiftachel, 2006). Due to climate crises, new civil demands are rising, opposing the petroleum industry, and calling for sustainable planning (Hein, 2018; Wilson et al., 2017). Through the last three centuries, authorities, economic actors, and inhabitants created and recreated physical and intangible borders via the port, thereby reshaping port and port cities (Fenster, 2019; Schumpeter, 2013).

\subsection{Port Cities: Tangible and Intangible Landscapes}

Port cities connect to their hinterlands and a network of other port cities. They produce flow and exchange through these intangible borders both in the physical aspect of infrastructure for water-land transport and in the imaginary aspect of the flow of ideas (Castells, 2000; Hein, 2016). Intangible borders are often discussed in the context of conflict-zone case studies, either religious, ethnic, national, or economic (Piquard \& Swenarton, 2011). Likewise, the study of ports and port cities in the fields of transportation, tourism, and immigration often discuss ports as spaces of conflict, examining attacks on port facilities and transit systems as well as conflicts revolving illegal travel, tourist misconduct, or tourist exploitation (Khosravi, 2010; Prentice, 2008).

Studies in architecture and urban history examine the design and development of port landscapes as spheres of conflict over domination, capital accumulation, identity, and heritage. These studies highlight the potency of the intangible elements of architecture and urban space in mediating and negotiating socio-spatial borders in the cityscape, in ethnic conflict areas like Cyprus or Israel-Palestine (AlSayyad, 2013; LeVine, 2001). These studies point to port landscapes as abstract boundaries, a phenomenological spatial experience that is primarily conceptual. In addition to tangible physical components in the landscape, ports include place-making boundaries that are time-contingent and shaped by human performance, with overlapping governance systems and flexible coalitions of actors, making them hard to decipher using mainstream categories (Hein, 2019).

Foucault conceptualizes the ship as the ultimate 'other space' (Foucault, 1985). A well-bounded physical space with clear tangible boundaries that, nonetheless, bears the inherent capacity to transcend the tangible borders of land and water, foreign and domestic, port and ship, making it an intangible instrument of border crossing and contamination (Dehaene \& De Cauter, 2008). Ports and port cities echo this design. However, the intangible border between land and waterways has not been appropriately historicized. This article explores Haifa's port and port city's history as a history of tangible and intangible landscapes designed for border crossing.

\section{Haifa Port City: Border Transformations}

This study involves archival research of the history of Haifa's porous urban landscape and port infrastructure. It focuses on primary sources documenting changes to the landscape-historical maps, land surveys, historical photographs, construction documents, and drawings produced by architects and engineers. Our findings point to a porous historiography, transgressing clearly demarcated time periods and geo-political frameworks.

\subsection{Haifa al-Jadida, A New Port City in the Eastern Mediterranean (1761-1850)}

At a time of weakness for the Ottoman empire, the local Muslim ruler of Galilee Zāhir al-'Umar al-Zaydānī (1761-1775) gained power over almost all of Palestine and today's southern Lebanon up to Sidon, controlling cotton-growing and manufacture around Acre and the Jezreel Valley (Philipp, 2001). The declining Acre Crusades port urged al-Umar to seek a new port and establish a new port city for commercial purposes. Old Haifa-Haifa al 'Atiqa-was a small town on the west coast of the Mediterranean Sea, on the southern entrance to Acre's Bay. With its two protecting forts, Haifa's mooring, the best in the eastern Mediterranean between Egypt and Turkey at the time, had safer docking conditions for ships. However, it needed more protection against pirates and weather conditions (Yazbak, 2013). In 1761 al-'Umar decided to build a new city 
three kilometres east into the bay by reusing stones of old Haifa to build the new fortified city and jetty (Figure 1; Oliphant, 1886). Seeking new markets for agricultural produce, al-'Umar strengthened connections with French commercial companies convincing them to embark at Haifa on their way to Tyre and Sidon (Carmel, 1985, 2010; Joudah, 2015; Philipp, 2001; Yazbak, 1998). Initiating the commercial relationship between cities overseas, shipping companies started anchoring at Acre's Bay regularly, creating an access point to northern Palestine by perforating Ottoman territorial borders and juxtaposing hierarchies of international trade.

The new fortified city of 20 dunam included souks and a mosque at its central public space by the shoreline, surrounded by residential quarters. Fortifications included a trapezoid-shaped longwall of 630 meters, a 270-meter base along the shoreline, and two castles, one on the hill above the city and another in Wādi Rushmiya. Old Haifa inhabitants, primarily Muslim, moved to the east quarter, above the administrative centre. The harbor attracted migrants to Haifa, including Christians of different sects who settled on the western side of the city (Yazbak, 1998). The city's administrative area managed its economic, religious, and cultural functions, including the Saray (government house), A-Za'ir mosque, and a customs house. The grain Bazar and other markets spread along the shoreline and dock, adjacent to Al-Jarina Mosque, opposite two churches. As in other traditional Muslim cities, residential quarters included narrow streets descending, down the hill, between blocks of gated courtyard family houses (Abu-Lughod, 1987; AlSayyad, 1995, 2013; Ben Hilell, 2020; Çelik, 1993; Jayyusi et al., 2008). Perpendicular streets parallel to the main road and shoreline followed the topography to create the city's grid. Residents built one-story Liwan houses and maintained small gardens in their walled plots. Some families also cultivated orchards on an agricultural plot for growing vegetables on the mountain's sloped terraces (Ben Hilell, 2020).

Al-'Umar's goal was to build a new secured port to attract more European shipping companies, gain tax profit on maritime trade, and protect the Haifa-Acre path from both pirates and Ottoman rulers (Yazbak, 1998). Despite his efforts, the town remained a closed community whose porosity remained small-scale.

\subsection{Hybrid Local-Cosmopolitan City (1850-1917)}

Half a century later, the porous nature of Haifa's port landscape intensified. Unharmed by Napoleon's conquest of Palestine in 1799 and the Egyptian conquest of Haifa in the 1830s, it was the only remaining harbour in the Eastern Mediterranean until the 1850s. As all ancient ports sank or piled with rubble and shipwrecksthe cases of Acre and Jaffa, where ships anchored in the sea, unloading goods into small boats to navigate between the rocky water (Gordon, 2006; Kark, 1984). The Crimean War led to the Paris agreement of 1856 which increased European presence in the region and established significant administrative and governmental changes that permitted non-Muslim religious freedom and equality (Çelik, 1993).

The Ottoman administration and residents aimed to transform Haifa into the modern centre of northern Palestine (Yazbak, 1998). At Haifa's quiet bay, several European shipping companies loaded agricultural

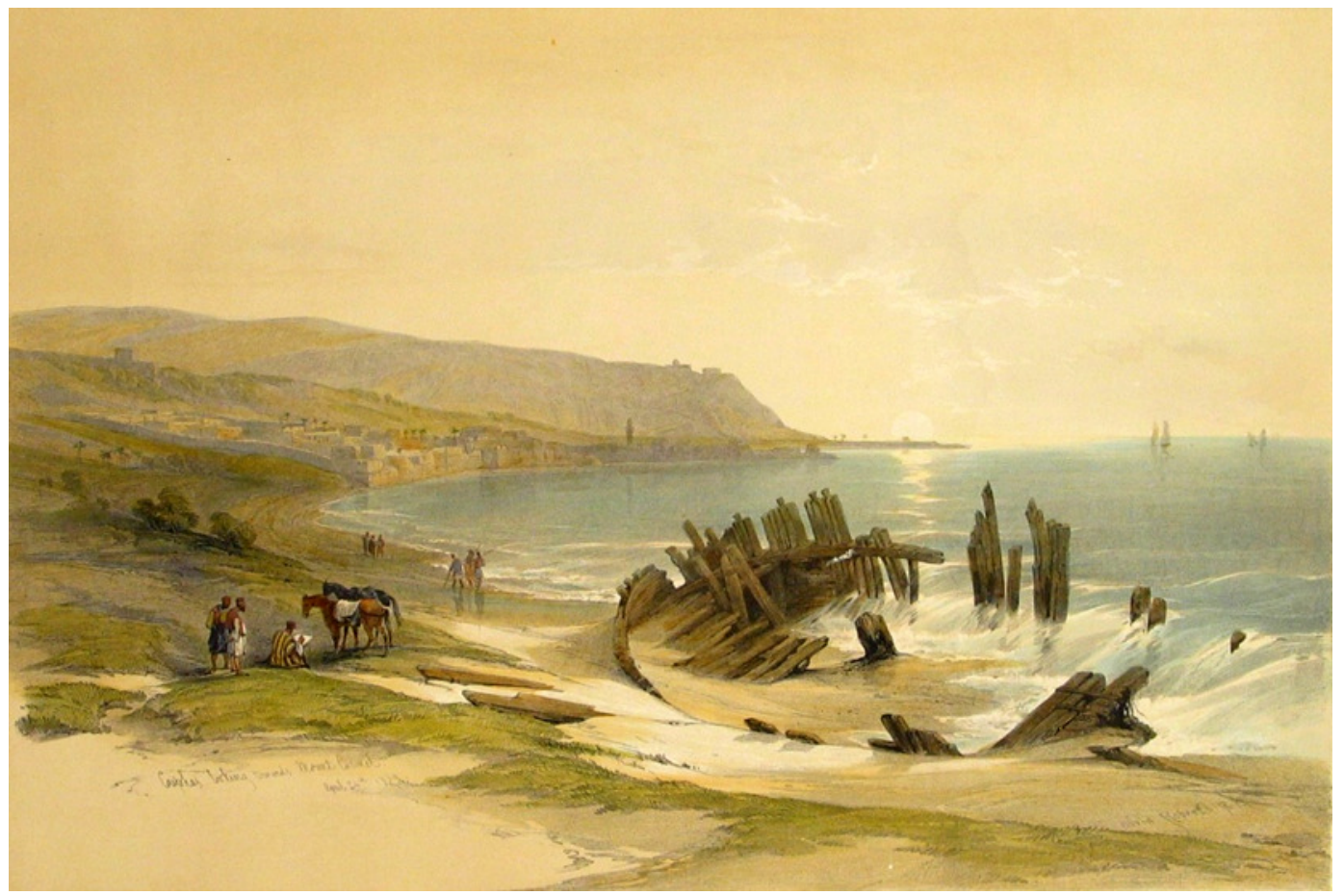

Figure 1. Haifa, looking towards Mount Carmel, April 1839. Source: Roberts (1839). 
products from Galilee, Hauran, and the Jezreel Valley. In 1854, a hydraulic press was installed on the dock to package cotton before loading. In 1855-1859 a 30-meter walled pier was built by the Russian Trading and Shipping Company, perpendicular to al-'Umar's dock to serve Christian pilgrims. A decade later, in 1866, the port's platform needed an extension due to sand flow blocking the ships' way. The city's Ottoman administrators appointed Gottlieb Schumacher, a local German-Templer architect, as district engineer to extend this pier by wooden and iron piles enabling the sand to flow rather than pile up (Ben-Artzi, 1994). Port infrastructure therefore positioned Haifa as the site where imperial and local borders turned porous.

Soon, this modest dock infrastructure no longer supported growth in agricultural export, served by new steam engine ships (Kitsikopoulos, 2013). In response, multiple modernization initiatives contributed to adjust port and city to the growing movement of people and goods; further puncturing its borders and increasing its porosity. Diverse initiative groups-a mix of Ottoman government, local entrepreneurs, bourgeoisie, urban migrants, European commercial companies, professional engineers, and pilgrims-generated a complex plethora of environmental developments with differing levels of porosity.

Modern developments included the harbor and breakwater, landed infrastructure to the port by train, roads, and bridges (Amit, 2007; Christensen, 2017; Simonowitz, 2014), as well as the city's waterfront, new neighbourhoods, and commercial facilities (Yazbak, 1998). In the 1880s, a new seafront was constructed upon 16,500 square meters of landfill designed for tying steam ships. It included a trapezoidal seafront wall protruding 5.5 meters above the wharf line. The new dock was served by a new 10-meter-wide road along the shore for camel caravans transporting the goods to Jaffa in the south, Acre in the north, and the Israel Valley to the east. Diverse entrepreneurs constructed massive warehouses of $50 \times 10$ meters on landfilled area for safe storage of imported goods (Figure 2). The plethora of infrastructure served the many actors involved. For example, during the 1890s a small breakwater was built in front of the Templar's colony for embarking passengers, in anticipation of the German Emperor's visit in 1989, while on the other side of the harbor a new breakwater connected to the railway. Each dock, breakwater and warehouse puncturing the tangible land-sea divide at a difference scale and for a different purpose.

One of these initiatives demonstrating how Haifa port infrastructure transformed demarcated affiliations and hierarchies of power, and ultimately its border landscape, was the construction of the Haifa-Damascus railway. Initiated in the 1880s by Laurence Oliphant and the local Sursock family, construction started but halted after 3 kilometres due to financial problems. In 1892, two railway companies resumed laying the railway line from Haifa to Damascus: the British Peeling and the Ottoman Syrian railway company. The railway's section between Haifa and Bisān (today's Beit She'an), connecting Damascus to Daraa, was planned by Schumacher. Dealing with competition from the Beirut-Damascus line, diverting agriculture export from Haifa to Beirut, as well as financial difficulties, stopped construction short with

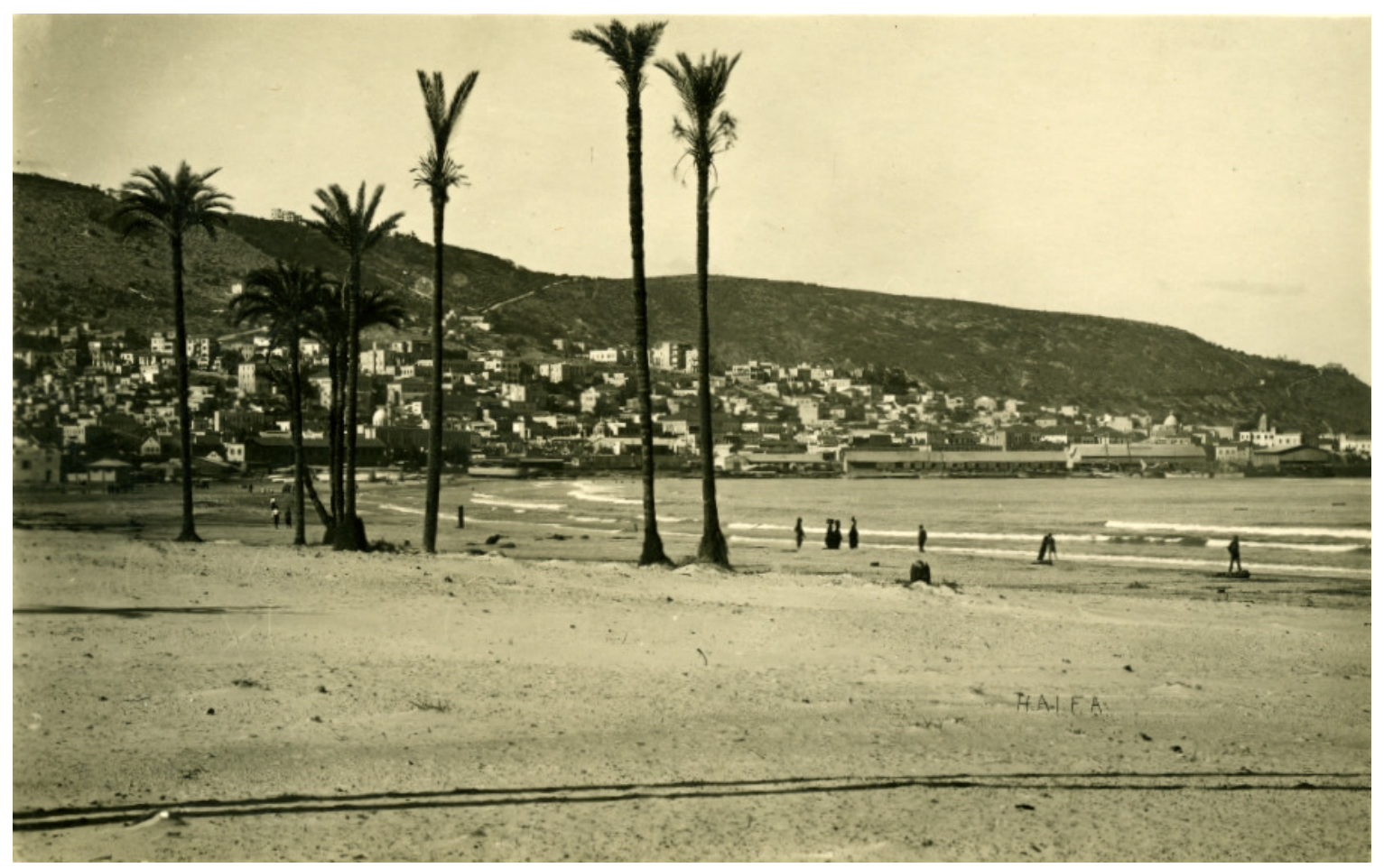

Figure 2. Postcard, unknown photographer, unknown issue date, Eli Roman Collection. 
only a 10-kilometre line completed (Ben Hilell, 2020; Goren \& Sahfran, 2006). In 1905, now promoted by Sultan Abdülhamid II as a tourism-pilgrimage Muslim project, the railroad connecting Haifa to Damascus was completed and connected to the Hijaz Railroad between the Empire's centre and holy city of Mecca (Christensen, 2017; Landau, 1979; Simonowitz, 2014). A total of 286 kilometres, Haifa's railway to Damascus included construction of 442 bridges, six viaducts, and seven tunnels and excavated passages (Amit, 2007; Ben Hilell, 2020; Kushner, 2018). The Haifa-Damascus section of the Hijaz Railway linked the Mediterranean Sea to the Empire's central railway line, transporting 16,000 tons of materials per year between 1903-1905 and establishing the 1400-kilometer Damascus-Medina railway.

Port development fostered three migration waves changing the city's human landscape and creating both tangible and intangible borders between the different groups. Between 1850-1870 immigrants included peasants of northern villages, entrepreneurs from Greater Syria, and first European settlers and consuls, each group settling in distinct areas of the city. The second migration wave of 1871-1904 brought primarily foreign communities including Maronites from Beirut and European communities who gathered around their consulates from Britain, France, Austria, Denmark, and Sardinia, and new consulates from Russia, Prussia, the United States, Greece, and the Netherlands, producing connections between Haifa and important port cities. The Templers' rural colony west of the city, and Bahá'íans colony marked the city's religious connection with distant communities (Carmel, 1985; Yazbak, 1998). The third wave of 1905-1912 included worker-migrants and changed the city's class landscape. Migration waves transformed Haifa from a small port station to the cosmopoliti- cal transportation and economic centre of the region. New connections between individuals and organizations enabled navigation in a growing sphere spanning the MENA and Europe.

Urban migration needs led to new neighbourhoods outside the city walls, pushing the town's reconstruction: City walls were demolished, their blocks used to construct the first new neighbourhoods, spreading to east, west, and up the mountain's slopes (Figures 3 and 4; Ben Hilell, 2020; Yazbak, 1998). Growing revenues from the port contributed to changes to the local vernacular Liwan house by additions of second and third floors forming a new hybrid local-Mediterranean model (Ben Hilell, 2020). Housing needs changed housing culture from gated family houses to villas and apartment houses that opened to the streets, rented for landless dwellers (Ben Hilell, 2020). Local stonemasonry techniques matched with imported architectural elements and materials created a new house model, the Centre Hall House, with redtiled roof (Fuchs, 1998). Modern public facilities including schools, hospitals, and banks served the cosmopolitan community of Haifa as meeting points for its diverse population as porous intersections in the tangible and intangible borders between them.

\subsection{Colonial Port City in British Mandate of Palestine (1917-1948)}

At the end of the First World War and the Ottoman Empire's collapse, the southern territory of 'Greater Syria,' which included the vilayets of Beirut, Aleppo, Damascus, and Jerusalem Mutasarrifiya, was divided by the victorious allies disregarding previous regional divisions: The British got the Mandate on Palestine and Iraq, France the Mandate on Syria and Lebanon (Fildis,

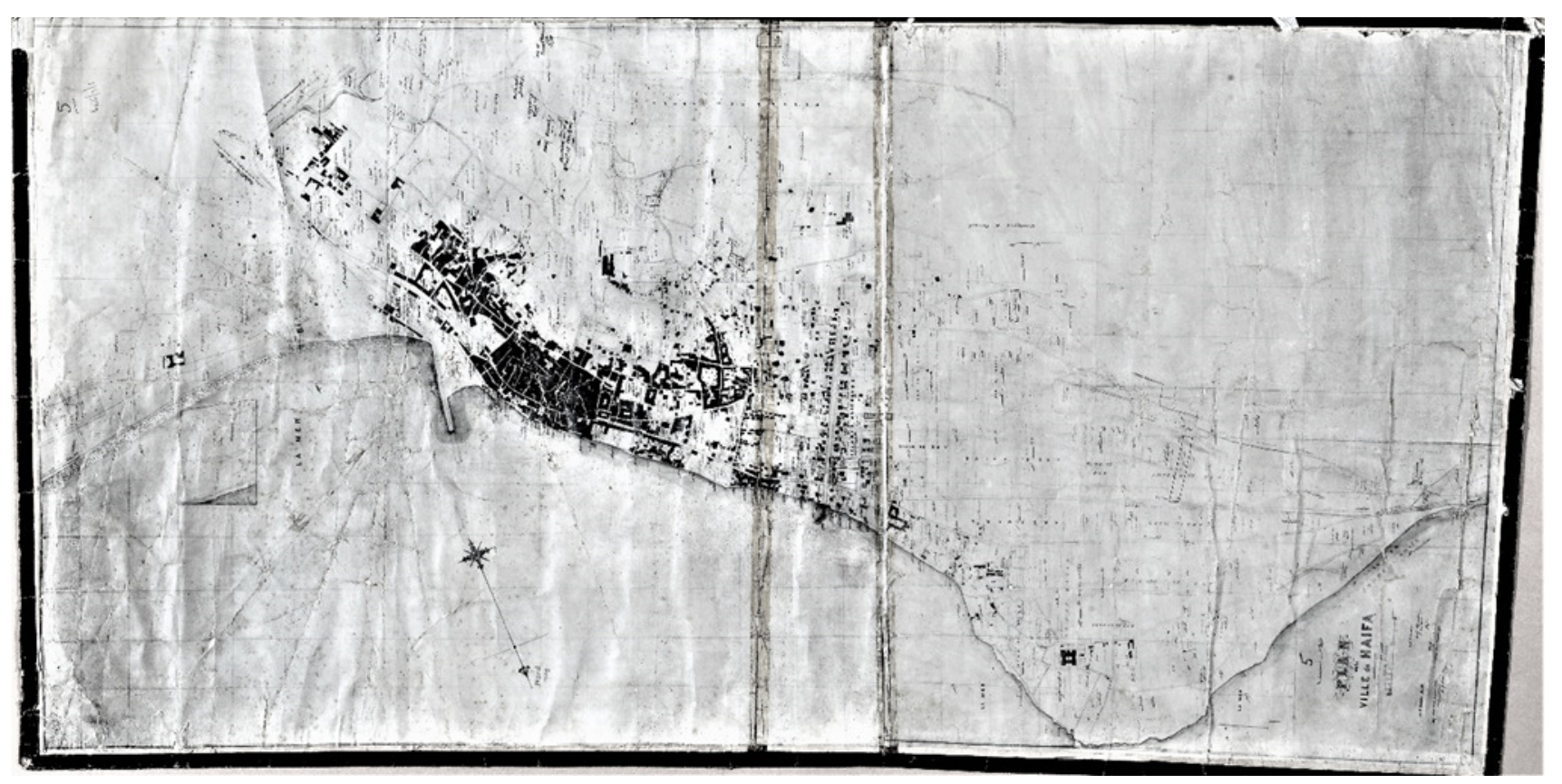

Figure 3. Haifa, 1911. Source: Schumacher (1911). 


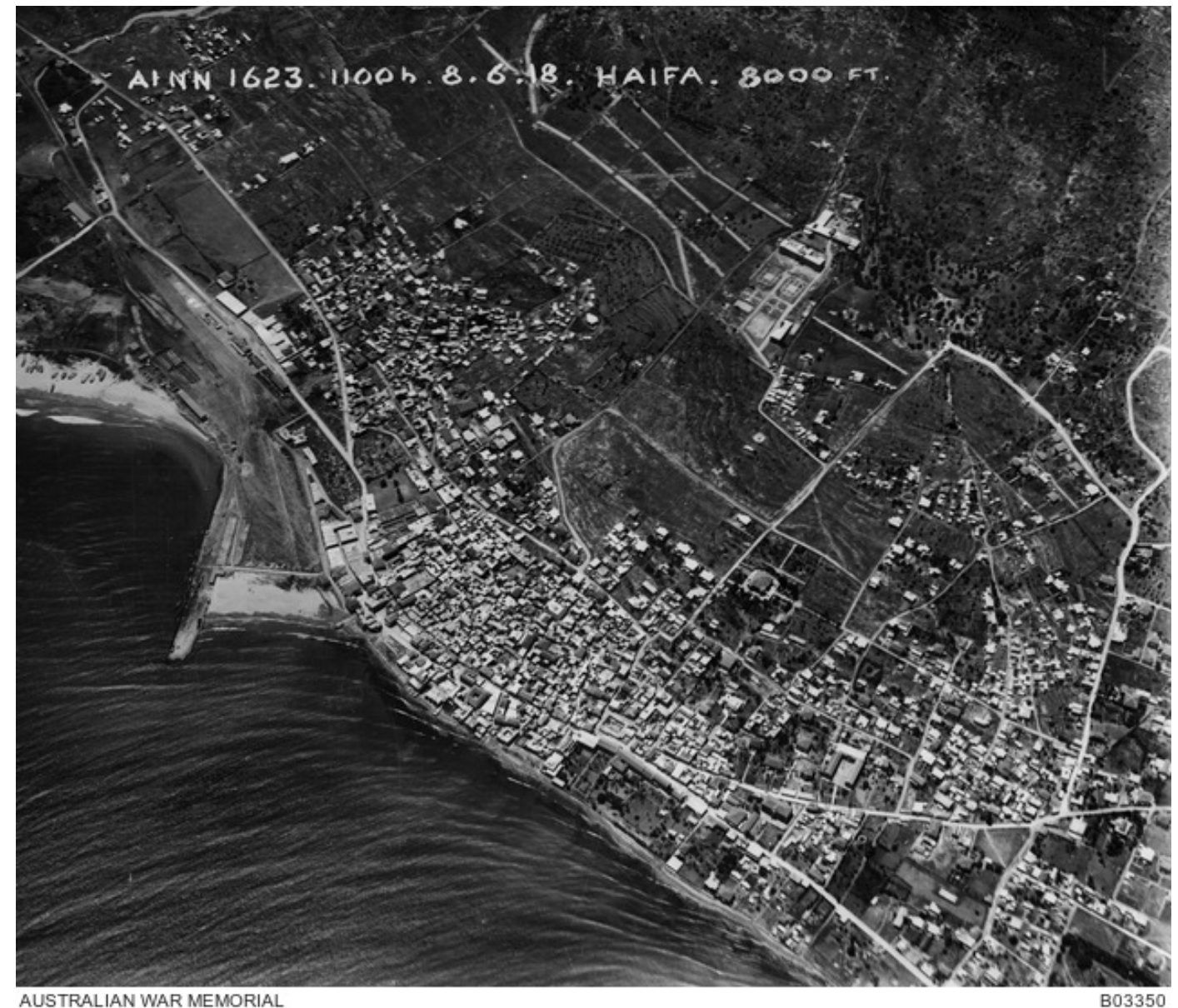

Figure 4. Aerial photographs of the Australian Air Force photographed on June 8, 1918. Source: Australian Air Force (1918).

2018; Yazbak, 2000). Haifa transformed from a regional Ottoman port city to a British economic and strategic colonial entry port to the oil-rich Middle East and India reflected on Haifa as part of the British empire (Mitchell, 2003), evident in the map of 1934 (Figure 5).

In 1925, the British-owned company Turkish Petroleum (later Iraq Petroleum Company) was granted sole rights for exploiting oil in Bagdad and Mosul requiring a deep-water port for exporting petroleum products (Kolodney \& Kallus, 2008). As a strategic imperial decision, the location of this new deep-water port was decided by Winston Churchill, Secretary of State for the Colonies, who appointed engineer Frederick Palmer to survey the region (Fine, 1998; Stern, 1981). Palmer's report rejected old ports in Jaffa, Gaza, Beirut, and Tripoli for their deteriorated state, or utilizing Port Fuad in Egypt. Haifa was selected for its natural bay, existing infrastructure connecting to the hinterland, and better defence, economic, and engineering aspects (Palmer, 1923). Local and international commercial companies played an important role in developing the new territories, promoting diverse initiatives to the High Commissioner of Palestine Herbert Samuel and local colonial authorities. The harbor was built between 1927-1933 with limestone from Atlit's quarry and 360 dunam landfill. Two breakwaters, the western one 2,210 meters long beginning at
Bat Galim, and the eastern, 765 meters long, started near the Kishon river's estuary, created a vast docking pool. Two piers extended the east landfills creating separate loading areas for oil products and general commodities. In 1928, the fuel terminal was separated from the commodities terminal by adding another small cooling mooring near the Kishon estuary (Figure 6).

New land connections with neighbouring countriesLebanon, Trans-Jordan, Egypt, and Iraq-require new land infrastructure. Therefore, new railway lines and pipelines to Iraq were constructed. British planner Clifford Holliday divided the vast landfilled area into three land use sections: the north strip for the port, the middle for the railroad, and the third for urban mix-use of offices and stores. An oil storage area built in front of the Ottoman rail station on the landfill, and additional 20 acres of oil storage facilities was added north to the breakwater in 1932 for Shell, Socony-Vacuum, and Iraq Petroleum Company use (Herbert, 1989). In 1934 the refineries were built connecting to the 998-kilometer pipeline from Kirkuk. The Iraq Petroleum Company constructed oil docks, submarine loading lines, and other terminal installations. In 1938 the first international airport was built near the Kishon to use 'Imperial Airways' amphibian aircrafts that maintained the line between Europe and Asia. 


\section{COGITATIO}

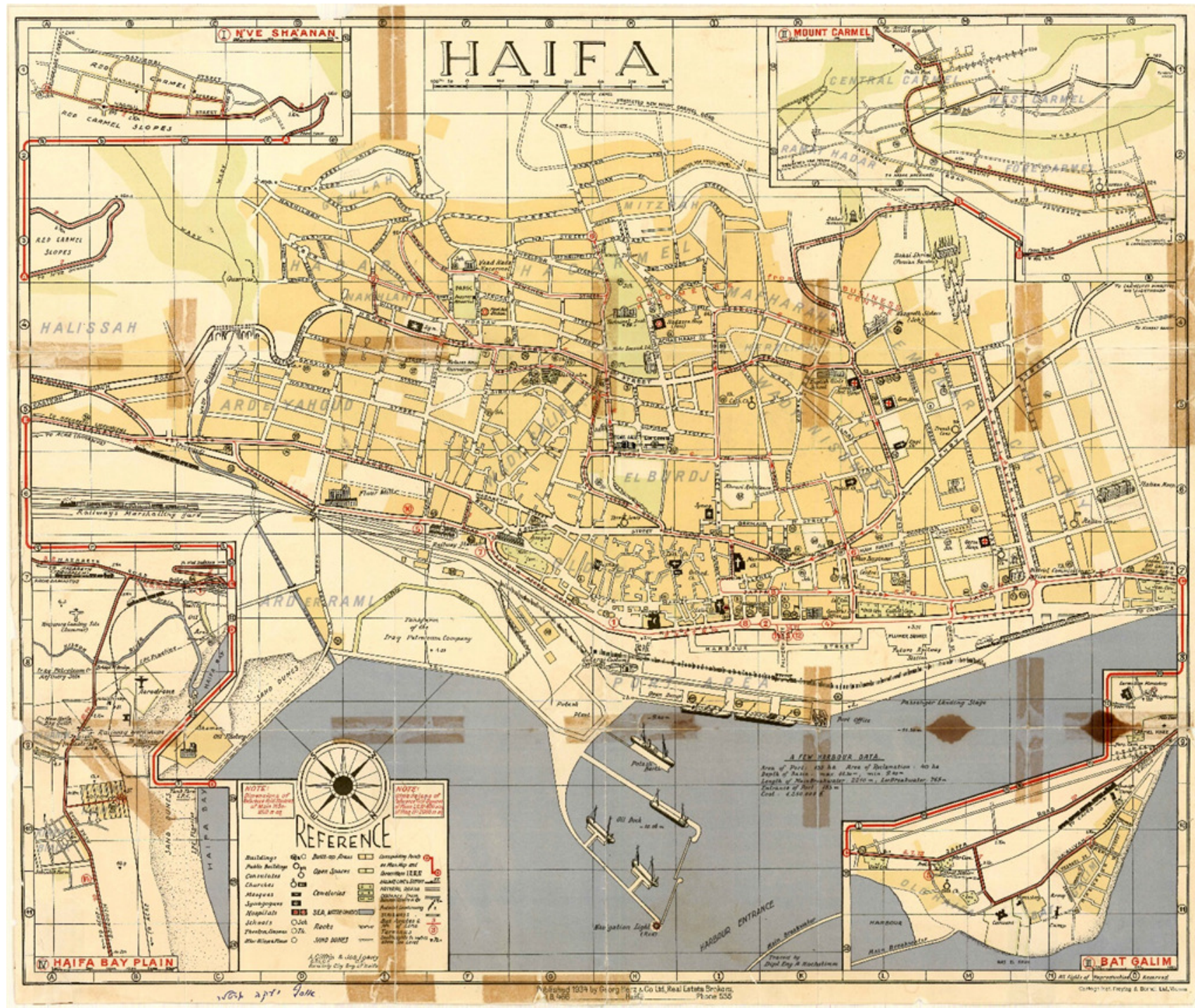

Figure 5. Haifa, 1934. Note: The bright yellow part is the filled era of the new deep-water harbor. Source: Ciffring and Loewy (1934).

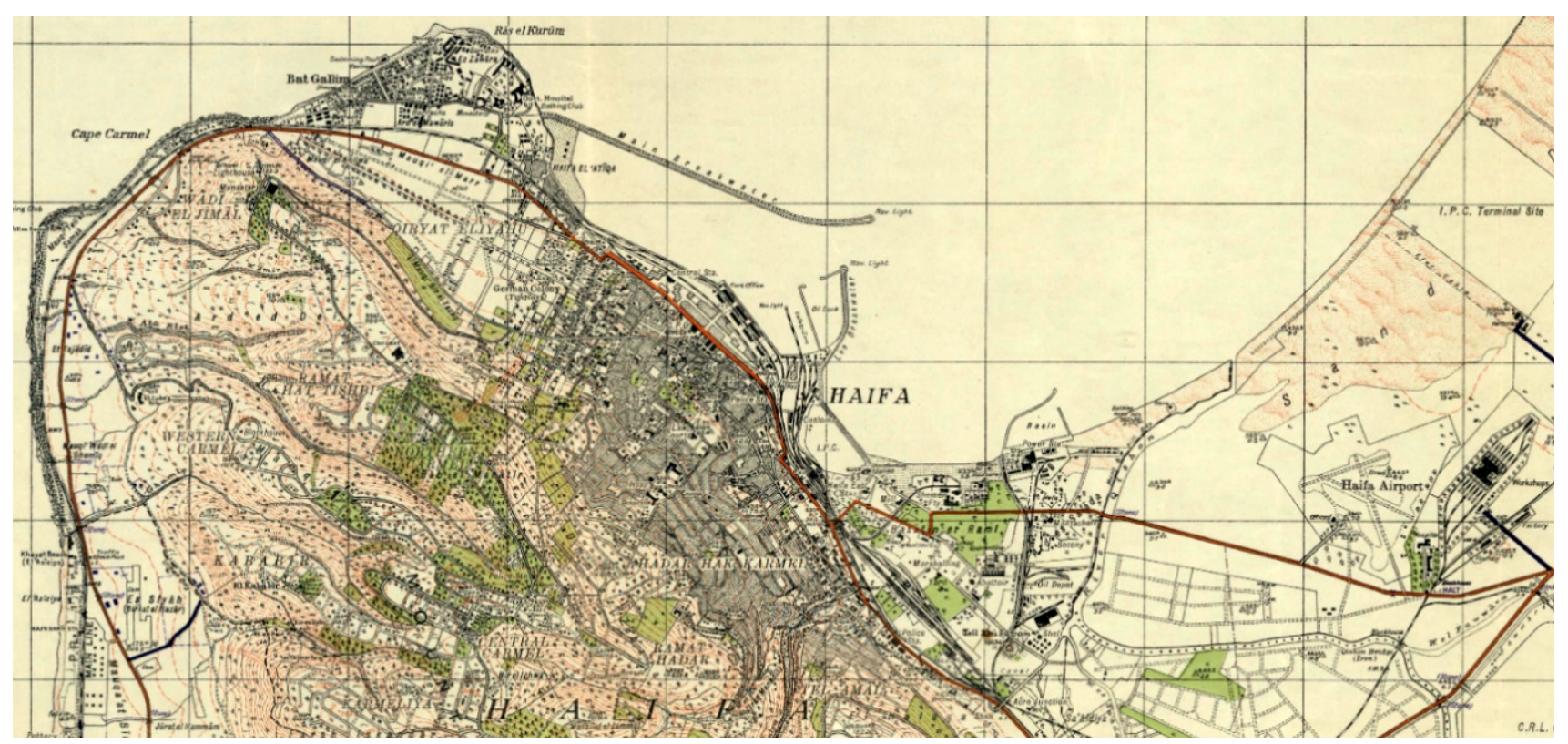

Figure 6. Haifa, 1942. Source: Haifa Municipal Archive (1942). 
Haifa city planning was extensive during the British Mandate. The British employed noted planners Patrick Geddes, Patrick Abercrombie, and Clifford Holliday to attach the port to the city, reflecting the empire's needs. The British financed and built local and national infrastructures and demolished areas they characterized as slums. Throughout the British colonies, 'cleaning' slum quarters by demolition and reconstruction legitimized modern planning and enforced new land-use zoning, public health, and hygienic standards (Abercrombie, 1935). As soon as the Patrick Geddes' survey and New City Plan of 1920 were completed, the demolition of Ottoman Haifa began. The first phase cleared space for George V Avenue crossing in the middle of the old town, followed by the Skeleton Zoning Scheme of 1934 and detailed plan for the Old City of 1938 for demolition of 335 dunams, only partly completed due to the 1936-1939 Arab Revolt and the 1948 war (Kolodney \& Kallus, 2008).

As a transit hub, many Mecca-bound Muslim pilgrims came through the port. Increasing numbers of Jewish immigrants entered Palestine through Haifa port, many stayed in the city due to diverse working opportunities in the port or one of the new factories. The city's population grew from 20,000 at the end of WWI (with 17,000 Arabs and 3,000 Jews) to about 145,140 inhabitants in 1946 (Yazbak, 1998). As a 'mixed city' with 70,910 Arabs and 74,230 Jews, the city developed new neighbourhoods that spread up mount Carmel. Most of the Arab population stayed downtown, while Jewish immigrants settled in new neighbourhoods uphill (see Figure 7). Out of seven mixed cities in Palestine, Haifa remained mixed until the British left on May 18, 1948. Since its first council election in 1927, the city elected a mixed municipality, cooperation that continued even as the Jewish-Arab conflict intensified at the national level (Goren, 2004; Kidron, 2020) and reflected civil society's prosperity with multiple joint businesses and culture (Goren, 2004; Sharfman \& Nachmias, 2006).

\subsection{National Port of Entry (1948-2000)}

With decolonization processes at the close of WWII, Haifa's borders changed again. The struggle over Palestine led to the 1948 war that divided the land and established new physical and political borders that eliminated Haifa's porous landscape by disconnecting its infrastructure to neighbouring countries and Iraq.

As a city, Haifa suffered traumatic demographical change between the United Nations 1947 declaration and close of the 1948 war. Half of its inhabitants, most of the Arab population, fled or were expelled through its port, leaving only 3,566 Christians and Muslims transferred to the Wadi Nisnas neighbourhood (Goren, 1999). Immediately after the war, the Haganah Jewish paramilitary organization demolished downtown Haifa (Goren, 1994), executing British plans for urban renewal while erasing the historical cityscape (Kolodney \& Kallus, 2008). This solidification of border landscapes in the context of national struggle involved the nationalization of $93 \%$ of lands as state property under a national-collectivist land regime (Jabareen, 2015; Yiftachel, 2006), displacing 780,000 Palestinians, and demolishing around 400 villages, towns, and cities, known as the Palestinian Nakba (Morris, 1987).

As the main port for the regionally isolated Israeli state, Haifa's became the main national port for entry

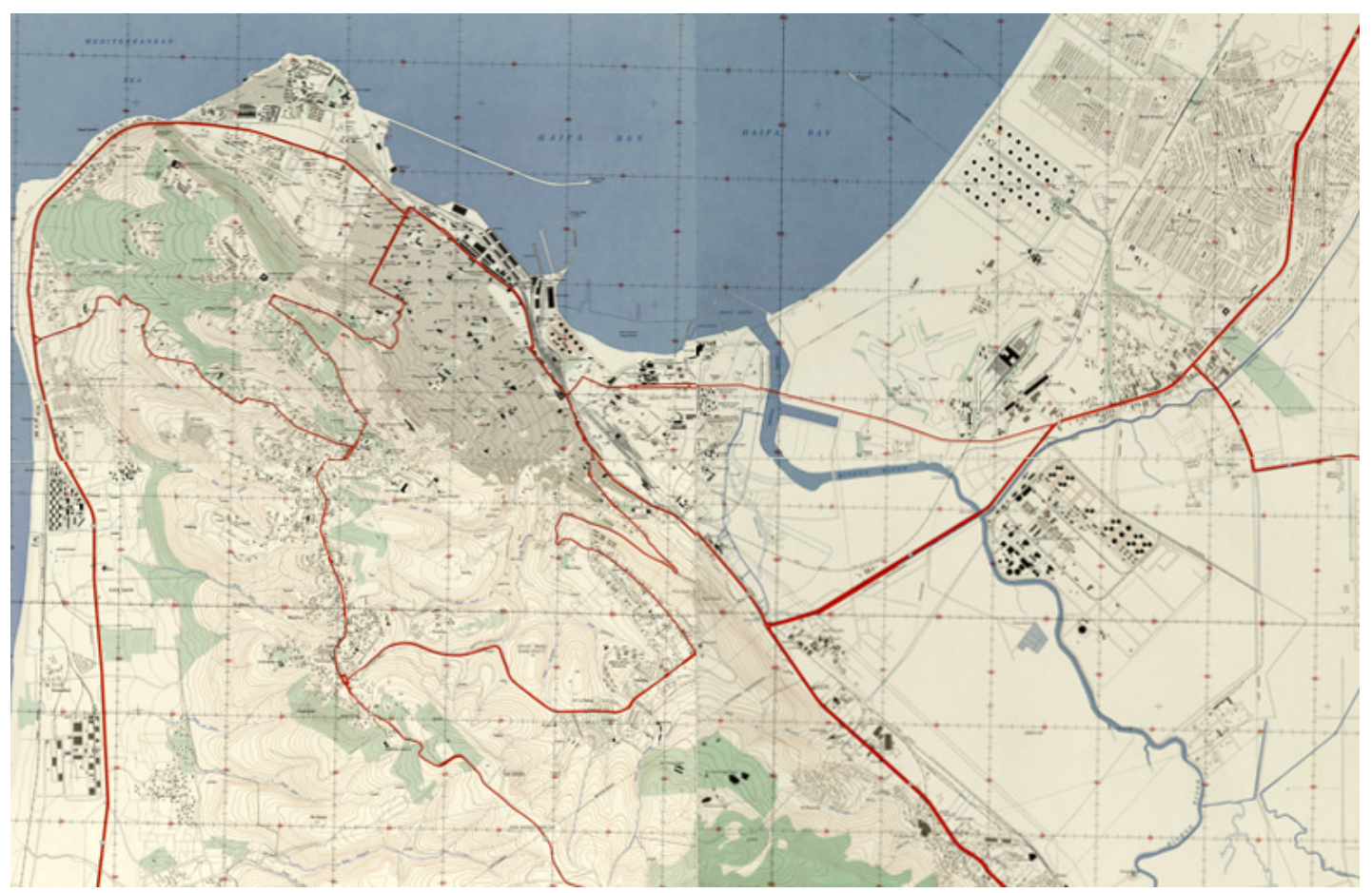

Figure 7. Haifa, 1958. Source: Junction of four maps of Haifa by Perry-Castaneda Library Map Collection (1958). 
and export, and main industrial centre. Haifa's economy transformed from commerce to industry, including chemical and fertilizer plants, oil refinery, foundries and steel mill, glassworks, motor-car assembly plants, electronic industry and power stations, textile mills, a shipyard, a cement plant, and so on (Rahav, 1976). Haifa became Israel's 'red city,' its inhabitants working in city factories, enlarging the city's population to 160,000 inhabitants for whom new worker housing was constructed.

The harbor was soon extended with new infrastructure to reflect the country's needs as main gateway for people and goods. Enlarged to serve as main immigration gate for Holocaust survivors and Jewish communities worldwide and a key port for exporting national products, with two deep-water wharves one for large passenger liners and the other for cargo vessels, amounting to $98 \%$ of trade and human transport. The Palmer gate on the middle section of the port was the country's main entrance for more than 900,000 immigrants during Israel's first decade. As main entry point for immigrants, the port's supporting infrastructure included Sha'ar Aliyah, an immigrant's temporal camp of 200 dunams, established on the former British Sent Lucas military camp. As main entry point for goods, the port included extensive storage area of 59,748 square meters in 18 sheds, one of them for potash in bulk, and open dumps counted 71,415 square meters and six-level luffing portal cranes (Rahav, 1976), most noted the Dagon granary a 65-meter-high building supplying bulk grain contains 200 storage cells for 20,000-ton grains. In addition, the civilian port, the Israeli Navy established a strong military port dominating the harbor's western part, including a United States navy port. Haifa's landscape thus gradually became more and more porous, serving civilian and military, national and international, commercial, and ideological flows of people, goods, and ideas.

During the 1950s, larger infrastructure was developed expanding porosity through Haifa port. A 110-ton floating crane and a fleet of modern mechanical handling equipment, tractors, trolleys, forklifts, mobile cranes, and conveyors were introduced. Between 1952-1954 the port was extended with a new auxiliary harbor on the Kishon estuary with a 70-meter-wide entrance and two breakwaters of 600 and 350 meters to serve smaller ships and free the main port for larger ships. The main breakwater extended by 450 meters. The 765 meters long Lee breakwater created a basin of 1,038 square meters, leaving 138 meters wide open to the port facing northeast and 12 meters deep, suitable for a maximum 10.5 meters long vessels. The overall main wharf of 1,541 meters long suitable for several vessels at the same time. Landfill of 200 dunams began in 1971, preparing for containerization on Carmel terminal, in three stages: The first enlarged the British terminal, adjacent to the Lee breakwater, completed in 1973 (Rahav, 1976), the second constructed in the 1980s, is the longest in Israel, 960 meters long for regular and cooling containers and hazardous materials, and the last one completed in 2010 (see Figure 8). Israel's dependency on Haifa's port was elevated in 1961 with the decision to build two additional harbors, in Ashdod and Eilat, each managed autonomously, consequently gradually diminishing state investment in the port.

\subsection{Global Node vs. Local Node (1977-Present)}

Today, $98 \%$ of Israel's foreign trade passes through seaports. International trade constitutes more than $60 \%$ of

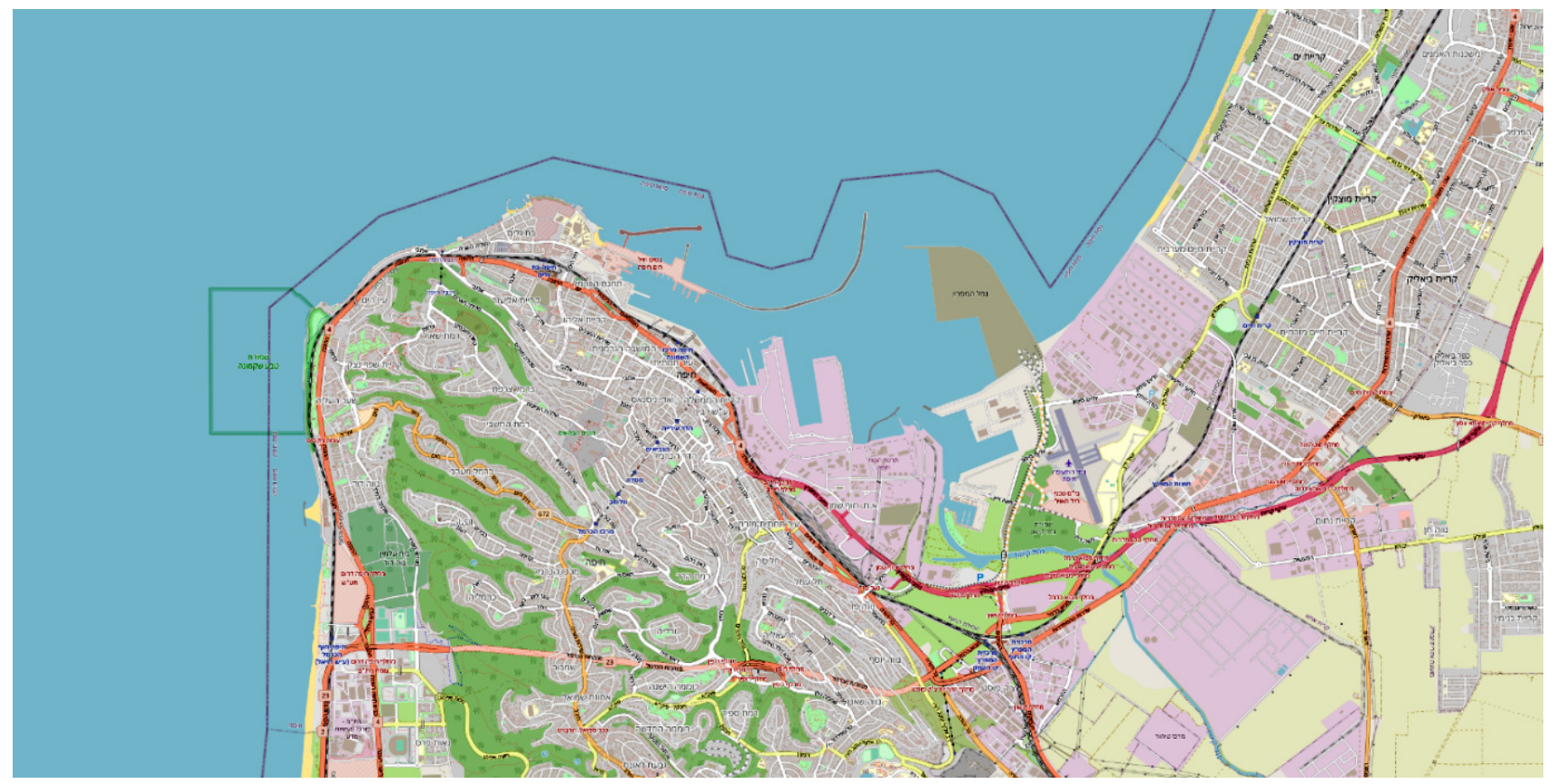

Figure 8. Haifa, 2021. Note: Chinese-corporate port in grey. Source: OpenStreetMap (2021). 
Israel's gross national product. Maritime trade doubles on average every five years (Zaltzman \& Armoni, 2020). Over the years, heavy petrochemical industrial factories were established near the refineries, including BAZAN (Oil Refineries Ltd), Haifa Chemicals, Carmel Olefins, and more than 27 risky factories (Raved \& Kuriel, 2016). Since the 1977 elections, the political agenda changed from socialist to national liberal capitalism. According to the current neoliberal-capitalistic approach, the government privatized the harbor, selling its seven departments originally managed and operated by the state through national companies to private companies. The 2015 Israeli government's gas agreement (Israeli Government, 2015) expresses the government's aspiration and interests to extend the industrial and petroleum fabrication in the Haifa Bay and establish a national petroleum council, separated from the Haifa civil council. Privatizing the harbor and expanding oil fabrication areas aims to develop natural gas, crude oil, and condensate reservoirs in Israel's territorial water, using local and foreign commercial companies, and expanding international trade by foreign investment. The transfer of responsibility to the market reduces the impact of public opinion and municipal governance and dismantle labour unions' power.

The 2015 gas agreement enabled the entrance of foreign companies to construct and operate Israeli ports. The Shanghai International Port Group Co. won the concession for constructing the new fuel port north of the Kishon (Yellinek, 2019). The new area, a large 728 dunam peninsula, was erected perpendicular to the east bay's shore (see Figure 9). The new deeper water terminal aims to compete and connect with significant harbors worldwide, suitable for mega container cargo ships. The Israel-United Arab Emirates normalization agreement of August 13, 2020, translated to commercial outcomes with the first mega-container ship from the Emirates that came on October 12, 2020 (Raved, 2020), opening the way for a regular commercial line between India, the Emirates, Israel, and the United States. On the other side of the harbor, large cruise ships regularly embark at the passenger's terminal. Again, serving as a node on a global network of maritime trade, in the new millennium, Haifa transformed into a global transportation hub, with its economy tied to the global network.

At the same time, Haifa's porosity to global corporate trade via infrastructure for mega container ships marginalizes local interests and concerns. Increased awareness of the oil industry's impact on the global climate crisis, a growing number of Haifa's citizens and environmental organizations attempted to resist the government's aspiration to expand fossil energy use and construction of the new Chinese port. New research on the connections between the oil industry, air, water, and soil pollution and public health (Nave \& Kuperman, 2016; Spector Ben-Ari, 2014; Wolfson et al., 2020), risk of earthquake in the Haifa Bay, and the threat from terrorist

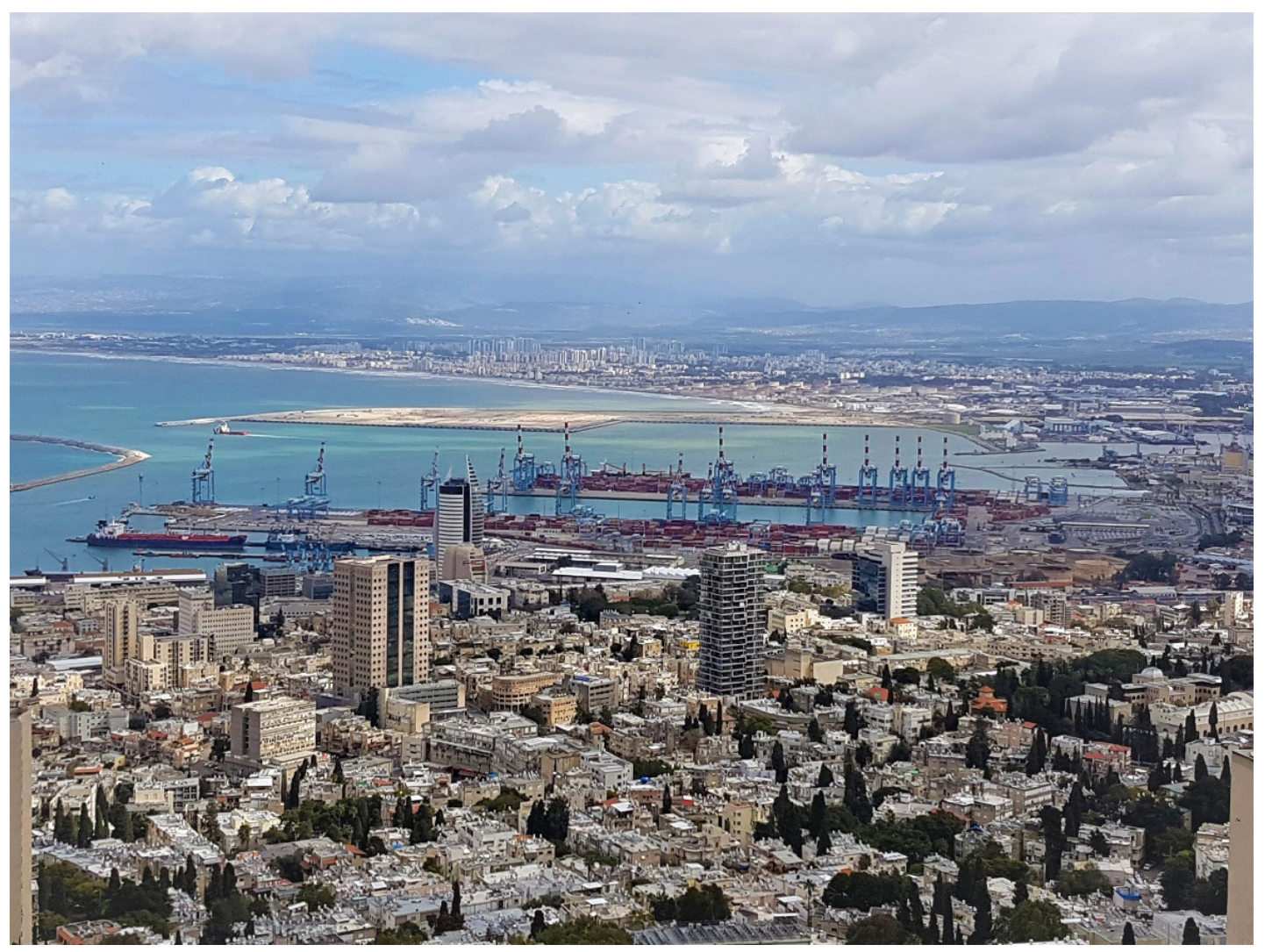

Figure 9. Haifa Port during the construction of the landfilled area for the Chinese petrol-harbor in 2020. Source: Keren Ben Hilell. 
attacks or bombings from Lebanon call for reducing risky factories and cleaning the area. As a result, Israel Lands Authority came up with a new plan for the Haifa Bay, 'Bay Gate Project,' also known as 'Bay of Innovation' (Yaar Architects, 2019), calling for the closure of the refineries and the conversion of Haifa Bay refineries to residential neighbourhoods, urban commerce, parks, and green lungs. What will be the result of public debate on the bay's future and how it will change Israel and the world's international connections need further study.

\section{Conclusion}

Haifa's port has undergone a series of dramatic transformations to its landscape and infrastructure since the mid-18th century, with implications and derivatives extending to decisions taken in Istanbul, London, and Jerusalem, goods sought in Marseille and Damascus, people coming from Europe and the MENA, and oil pumped from Basra. Haifa was inaugurated as a port city in the Eastern Mediterranean by a new local ruler interested in attracting French ships and exporting cotton and other agricultural products to Europe. Nevertheless, Haifa's walled city town planning kept the city at the local level. With the restructuring of the Ottoman Empire, Haifa served as a local-cosmopolitan hub for modernization initiated by a mix of Ottoman government, European commercial companies, local entrepreneurs, urban migrants, and professional engineers, constructing railway connections inland and a deep-water docking pool connecting vaster geographies through land and sea and producing modern grid-based city planning. International borders redrawn after WWI included Haifa in the British Mandate over Palestine, with new landed connections to Iraq, changing the nature of goods and requiring infrastructure for the transport of oil, a military port, extensive landfills, and significant city planning initiatives. With the 1948 war and the establishment of the State of Israel, Haifa became the main port of entry for goods and immigration, with significant immigrant camps and worker housing, grain storage facilities, and navy bases. The privatization of the port in the 2000s and the concession for a new deep-water container port by a Chinese corporation transformed the national port into a global transportation hub, despite labour unions and environmental activist's protests. While scholarly attention has been focusing on Haifa's tangible borders and bracketed historical periods, this article focuses on the ways in which port and city infrastructure engage in constant puncturing of tangible borders between water and land, empire, and colony, local and global.

The constant redrawing of Haifa borders between port and city, population, and commercial concerns, national/local and global, has shaped Haifa port and city. While Haifa's research tends to study well-bracketed historical periods dominated by grand power structures, this study focused on Haifa's port as an intangible, porous border that challenges the accepted literature with find- ings concerning the role of water and land transportation infrastructure in shaping both port and city.

\section{Acknowledgments}

Publication of this article was supported by the Shlomo Glass and Penny Balaban foundation scholarship for Advanced Research in Israel History and Heritage, and the Faculty of Architecture and Town Planning Faculty at the Technion, IIT.

\section{Conflict of Interests}

The authors declare no conflict of interests.

\section{References}

Abercrombie, P. (1935). Slum clearance and planning: The re-modelling of towns and their external growth. The Town Planning Review, 16(3), 195-208.

Abu-Lughod, J. L. (1987). The Islamic city-historic myth, Islamic essence, and contemporary relevance. International Journal of Middle East Studies, 19(2), 155-176.

Allweil, Y. (2016). Plantation: Modern-vernacular housing and settlement in Ottoman Palestine, 1858-1918. Architecture Beyond Europe (ABE), 9, 1-25.

Allweil, Y. (2017). Homeland: Zionism as housing regime, 1860-2011. Routledge.

AlSayyad, N. (1995). From vernacularism to globalism: The temporal reality of traditional settlements. Traditional Dwellings and Settlements Review, 1, 13-24.

AlSayyad, N. (2013). The fundamentalist city, medieval modernity, and the Arab Spring. Space and Polity, 3, 270-283.

Amit, T. (2007). Laurence oliphant: Financial sources for his activities in Palestine in the 1880s. Palestine Exploration Quarterly, 139(3), 205-212.

Australian Air Force. (1918). Aerial photographs of the Australian Air Force [Photograph]. Haifa Museums Collection.

Barrett, R., \& Worden, D. (Eds.). (2014). Oil culture. University of Minnesota Press.

Ben-Artzi, Y. (1994). Unrealized development plans for Haifa at the end of the $19^{\text {th }}$ century. Cathedra: For the History of Israel and Its Yishuv, 73, 62-82.

Ben Hilell, K. (2020). Modernization and urbanization processes of Haifa and Northern Palestine in the Late Ottoman Era (1850-1917): Regional infrastructure establishment, urban development, and changes in residential culture [Master dissertation, Technion IIT]. Hal. https://tel.archives-ouvertes.fr/tel-01586147

Carmel, A. (1985). The activities of the European powers in Palestine, 1799-1914. Institute of Middle Eastern Studies of the University of Haifa.

Carmel, A. (2010). Ottoman Haifa: A history of four centuries under Turkish rule. Bloomsbury Publishing. 
Castells, M. (2000). The rise of the network society (2nd ed.). Wiley.

Çelik, Z. (1993). The remaking of Istanbul: Portrait of an Ottoman city in the nineteenth century. University of Washington Press.

Christensen, P. H. (2017). Germany and the Ottoman railways: Art, empire, and infrastructure. Yale University Press.

Ciffring, A., \& Loewy, J. (1934). Haifa. Haifa Museum collection.

Dehaene, M., \& De Cauter, L. (Eds.). (2008). Heterotopia and the city: Public space in a postcivil society. Routledge.

Driessen, H. (2005). Mediterranean port cities: Cosmopolitanism reconsidered. History and Anthropology, 16(1), 129-141.

Dündar, Ş. G., Karataş, N., Erdin, H. E., \& Lorens, P. (Eds.). (2014). New faces of harbour cities. Scholars Publishing.

Fenster, T. (2019). Creative destruction in urban planning procedures: The language of 'renewal' and 'exploitation,' Urban Geography, 40(1), 37-57.

Fildis, A. T. (2018). France's imperial ambitions and the establishment of the French mandate in Syria. Joeep: Journal of Economies and Policy, 3(1), 1-9.

Fine, J. (1998). British policy towards the development of Haifa Harbor, 1906-1924: Strategic considerations. Qatedrah le-tôldôt Eres Yiśra'el el we-yîššûbah, 1998(89), 127-154.

Foucault, M. (1985). Discipline and punish: The birth of the prison (2nd ed.). Vintage.

Fuchs, R. (1998). Palestinian vernacular architecture: The Ottoman connection. In S. Ireland \& W. Bechhoefer (Eds.), The Ottoman house: Papers from the Amasya symposium, 24-27 September 1996 (pp. 54-74). British Institute of Archaeology at Ankara, University of Warwick.

Gordon, G. (2006). The production of roof tiles in Palestine. Zmanim: Quarterly History, 2006(96; Special issue: Milestones - Beginnings of architecture in Palestine), 58-67.

Goren, T. (1994). The history of the disappearance of the "Old City" from the perspective of Haifa, 1948-1951. Horizons in Geography, 1994(40/41), 57-81.

Goren, T. (1999). Changes in the design of the urban space of the Arabs of Haifa during the Israeli War of Independence. Middle Eastern Studies, 35(1), 115-133.

Goren, T. (2004). Separate or mixed municipalities? Attitudes of Jewish Yishuv leadership to the mixed municipality during the British mandate: The case of Haifa. Israel Studies, 9(1), 101-124.

Goren, T., \& Sahfran, Y. (2006). License to build a railway. Et_Mol: A Magazine for the History of the Land of Israel and the People of Israel, 185, 2-6.

Graham, S., \& Healey, P. (1999). Relational concepts of space and place: Issues for planning theory and practice. European Planning Studies, 7(5), 623-646.
Haifa Municipal Archive. (1942). Haifa.

Hein, C. (2010). Shaping Tokyo: Land development and planning practice in the early modern Japanese metropolis. Journal of Urban History, 36(4), 447-484.

Hein, C. (Ed.). (2011). Port cities: Dynamic landscapes and global networks. Routledge.

Hein, C. (2014). Port cities and urban wealth: Between global networks and local transformations. International Journal of Global Environmental Issues, 13(2/4), 339-361.

Hein, C. (2016). Port cities and urban waterfronts: How localized planning ignores water as a connector. Wiley Interdisciplinary Reviews: Water, 3(3), 419-438.

Hein, C. (2018). Oil spaces: The global petroleumscape in the Rotterdam/The Hague area. Journal of Urban History, 44(5), 887-929.

Hein, C. (2019). The port cityscape: Spatial and institutional approaches to port city relationships. PORTUSplus, 8, 1-8.

Heley, J. (2013). Soft spaces, fuzzy boundaries and spatial governance in post-devolution Wales. International Journal of Urban and Regional Research, 37(4), 1325-1348.

Herbert, G. (1989). Crossroads: Imperial priorities and regional perspectives in the planning of Haifa, 1918-1939. Planning Perspective, 4(3), 313-331.

Hoyle, B. S. (1989). The port-city interface: Trends, problems and examples. Geoforum, 4, 429-435.

Hoyle, B. S., Pinder, D. A., \& Husain, M. S. (1988). Revitalizing the waterfront: International dimensions of waterfront redevelopment. Belhaven Press.

Israeli Government. (2015). Outline for increasing the amount of natural gas produced from the "Tamar" natural gas field and rapid development of the natural gas fields "Levitan," "Carish" and "Tanin" and other natural gas fields (Government Resolution No. 476). https://www.gov.il/he/Departments/ policies/2015_dec476

Jabareen, Y. (2015). Territoriality of negation: Coproduction of "creative destruction" in Israel. Geoforum, 66, 11-25.

Jayyusi, S. K., Holod, R., Petruccioli, A., \& Raymond, A. (Eds.). (2008). The city in the Islamic world. Brill.

Joudah, A. (2015). Zahir al-'Umar and the first autonomous regime in Ottoman Palestine (1744-1775). Jerusalem Quarterly, 63, Article 72.

Kark, R. (1984). Changing patterns of landownership in nineteenth-century Palestine: The European influence. Journal of Historical Geography, 10(4), 357-384.

Kark, R., \& Frantzman, S. J. (2010). Bedouin, Abdül Hamid II, British land settlement and Zionism: The Baysan valley and sub-district 1831-1948. Israel Studies, 15(2), 49-79.

Khosravi, S. (2010). 'Illegal' traveller: An autoethnography of borders. Springer.

Kidron, A. (2020). When colonialism and nationalism 
meet but speak a different language: The case of Haifa during the British mandate. British Journal of Middle Eastern Studies. https://doi.org/10.1080/ 13530194.2020.1825928

King, A. D. (2015). Urbanism, colonialism, and the worldeconomy. Routledge.

Kitsikopoulos, H. (2013). From hero to newcomer: The critical scientific and technological developments that led to the invention of the engine. Proceedings of the American Philosophical Society, 157(3), 304-344.

Kolodney, Z., \& Kallus, R. (2008). From colonial to national landscape: Producing Haifa's cityscape. Planning Perspectives, 23(3), 323-348.

Kozlovsky, R., \& Grobman, Y. J. (2017). The blue garden: Coastal infrastructure as ecologically enhanced wavescapes. Landscape Research, 42(5), 439-454.

Kushner, D. (2018). The Haifa-Damascus railway: The British phase (1890-1902). Cathedra: For the History of Eretz Israel and Its Yishuv, 2018(55), 89-109.

Landau, J. M. (Ed.). (1979). Abdul-Hamid's Palestine: Rare century-old photographs from the private collection of the Ottoman Sultan. André Deutsch.

Lefebvre, H. (1991). The production of space. Wiley.

LeVine, M. (2001). "The "new-old Jaffa": Tourism, gentrification and the battle for Tel Aviv's Arab neighbourhood. In N. AlSayyad (Ed.), Consuming tradition, manufacturing heritage: Global norms and urban forms in the age of tourism (pp. 240-272). Routledge.

McGovern, S. J. (2008). Evolving visions of waterfront development in postindustrial Philadelphia: The formative role of elite ideologies. Journal of Planning History, 7(4), 295-326.

Meyer, H. (2003). City and port: The transformation of port cities: London, Barcelona, New York and Rotterdam. International Books.

Miller, M. B. (2012). Europe and the maritime world: A twentieth century history. Cambridge University Press.

Mitchell, D. (2003). Cultural landscapes: Just landscapes or landscapes of justice? Progress in Human Geography, 27(6), 787-796.

Morris, B. (1987). The birth of the Palestinian refugee problem, 1947-1949. Cambridge University Press.

Nave, E., \& Kuperman, H. (2016). The condensate inside the gas: A report on condensed oil discoveries that Israel has found. EPIDELLA. https://www. zerowaste.co.il/wp-content/uploads/2018/09/\%D7 \%94\%D7\%A7\%D7\%95\%D7\%A0\%D7\%93\%D7\%A0 \%D7\%A1\%D7\%98-\%D7\%A9\%D7\%91\%D7\%AA\%D7 \%95\%D7\%9A-\%D7\%94\%D7\%92\%D7\%96-\%D7\%93 \%D7\%95\%D7\%97-27.pdf

Oliphant, L. (1886). Haifa, or life in modem Palestine. Harper \& Brothers.

OpenStreetMap. (2021). Haifa. https://www.openstreet map.org/\#map = 13/32.8174/35.0199\&layers $=$ C

Paasi, A., \& Zimmerbauer, K. (2016). Penumbral borders and planning paradoxes: Relational thinking and the question of borders in spatial planning. Environment and Planning $A, 48(1)$, 75-93.

Palmer, F. (1923). Report on facilities of harbor provision for Palestine. Eyre and Spottiswoode.

Perry-Castaneda Library Map Collection. (1958). Haifa, 1:10,000, Edition 2-T-AMS, Series K931: U.S. Army map service, 1958 [Maps]. https://legacy.lib.utexas. edu/maps/israel.html

Philipp, T. (2001). Acre: The rise and fall of a Palestinian city, 1730-1831. Columbia University Press. https:// doi.org/10.7312/phil12326

Piquard, B., \& Swenarton, M. (2011). Learning from architecture and conflict. The Journal of Architecture 16(1), 1-13.

Prentice, B. E. (2008). Tangible and intangible benefits of transportation security measures. Journal of Transportation Security, 1(1), 3-14.

Rahav, I. (1976). Haifa port. Michael Ratner collection. The Avie and Sarah Arenson Built Heritage Research Centre Collection, Faculty of Architecture and Town Planning, Technion, Haifa, Israel.

Raved, A. (2020). For the first time: A ship with cargo from the UAE docked at the port of Haifa. Ynet. https:// www.ynet.co.il/economy/article/S1N1r00bPw

Raved, A., \& Kuriel, A. (2016). A map of the "ticking bombs" from Haifa Bay. Ynet. https://www.ynet.co. il/articles/0, 7340, L-4898695,00.html

Roberts, D. (1839). Haifa, looking towards Mount Carmel [Lithography]. National Maritime Museum Collection, Haifa Museums.

Said, E. (1979). Orientalism. Vintage Books.

Schumacher, G. (1911). Haifa map. Elyachar Central Library Collection, Technion.

Schumpeter, J. A. (2013). Capitalism, socialism and democracy. Routledge.

Sharfman, D. \& Nachmias, E. (Eds.). (2006). Tea on the casino terrace: Coexistence during the British Mandate 1920-1948. Mispaton.

Simonowitz, D. (2014). The mobile matrix: The Hijaz railway as ritual space and generator of space. International Journal of Islamic Architecture, 3(2), 303-340.

Smith, H., \& Ferrari, M. S. G. (Eds.). (2012). Waterfront regeneration: Experiences in city-building. Routledge.

Spector Ben-Ari, S. (2014). Environmental and planning issues in Haifa Bay: The Bazan complex and the northern lands program. Knesset Research and Information Centre. http://www.knesset.gov.il/committees/ heb/material/data/pnim2015-07-01.pdf

Stern, S. (1981). The dispute concerning the construction of Haifa port during the British Mandate. Cathedra: For the History of Israel and Its Yishuv, 21, 171-186.

Szeman, I. (2012). Crude aesthetics: The politics of oil documentaries. Journal of American Studies, 46(2), 423-439.

Watts, M. (2009). Crude politics: Life and death on the Nigerian oil fields. Niger Delta Economies of Violance Working Papers, 25, 1-27. 
Wilson, S. L., Carlson, A., \& Szeman, I. (Eds.). (2017). Petrocultures: Oil, energy, and culture. McGillQueen's University Press.

Wolfson, A., Ayalon, O., \& Madar, D. (2020). National strategy for framing and prioritizing environmental protection research and development topics. Sustainability, 12(18), 20-74.

Yaar Architects. (2019). Bay Gate project. https:// infospot.co.il/Content/UserFiles/Upload/\%D7\%AA \%D7\%95\%D7\%9B\%D7\%A0\%D7\%99\%D7\%AA\%20 \%D7\%A0\%D7\%99\%D7\%A7\%D7\%95\%D7\%99\%20 \%D7\%9E\%D7\%A4\%D7\%A8\%D7\%A5\%20\%D7\%97 \%D7\%99\%D7\%A4\%D7\%94.pdf

Yazbak, M. (1998). Haifa in the late Ottoman period, 1864-1914: A Muslim town in transition (Vol. 16). Brill.
Yazbak, M. (2000). From poverty to revolt: Economic factors in the outbreak of the 1936 rebellion in Palestine. Middle Eastern Studies, 36(3), 93-113.

Yazbak, M. (2013). The politics of trade and power: Dahir al-Umar and the making of early modern Palestine. Journal of the Economic and Social History of the Orient, 56(4/5), 696-736.

Yellinek, R. (2019). US-Chinese competition over the Haifa port. BESA Center Perspectives, Article 1071.

Yiftachel, O. (2006). Ethnocracy: Land and identity politics in Israel/Palestine. University of Pennsylvania Press.

Zaltzman, M., \& Armoni, A. (2020). Haifa port: Seeing the future, a digital information booklet. HAIFAPORT. https://www.haifaport.co.il/our-story

\section{About the Authors}

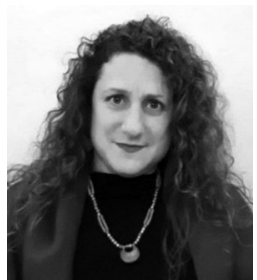

Keren Ben Hilell is a PhD Student in the Faculty of Architecture and Town Planning at the Technion, Israel, and a Member of the Housing Architecture, History and Theory research group. She is an active Artist and Curator holding a bachelor's degree with honors (BFA) from the Art Department at Bezalel Academy of Art, and Design, a master's degree (MA) from the Art History department at Haifa University, and a master's degree (MSc) from the Faculty of Architecture and Town Planning at the Technion.

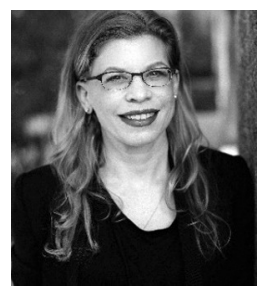

Yael Allweil is Associate Professor in the Faculty of Architecture and Town Planning, Technion, Israel, where she heads the HousingLab: History and Future of Living research group. She completed her PhD in architecture history at UC Berkeley. Her research was published in the monograph Homeland: Zionism as Housing Regime 1860-2011 (Routledge, 2017) and journal articles in Urban Studies, ACME, City, Urban Planning and others. Member of Israel Young Academy. Her research was funded by the Fulbright Foundation, Graham Foundation, Israel Science Foundation, and Israel Institute for Advanced Studies (IIAS). 